\title{
Nonpathogenic Simian Immunodeficiency Virus Infections
}

\author{
Nichole R. Klatt ${ }^{1}$, Guido Silvestri ${ }^{2}$, and Vanessa Hirsch ${ }^{1}$ \\ ${ }^{1}$ Laboratory of Molecular Microbiology, NIAID, NIH, Bethesda, Maryland 20892 \\ ${ }^{2}$ Department of Pathology and Laboratory Medicine, Emory University School of Medicine, and \\ Yerkes National Primate Research Center, Atlanta, Georgia 30322 \\ Correspondence: vhirsch@niaid.nih.gov
}

\begin{abstract}
The simian immunodeficiency viruses (SIVs) are a diverse group of viruses that naturally infect a wide range of African primates, including African green monkeys (AGMs) and sooty mangabey monkeys (SMs). Although natural infection is widespread in feral populations of AGMs and SMs, this infection generally does not result in immunodeficiency. However, experimental inoculation of Asian macaques results in an immunodeficiency syndrome remarkably similar to human AIDS. Thus, natural nonprogressive SIV infections appear to represent an evolutionary adaptation between these animals and their primate lentiviruses. Curiously, these animals maintain robust virus replication but have evolved strategies to avoid disease progression. Adaptations observed in these primates include phenotypic changes to $\mathrm{CD}^{+}{ }^{+} \mathrm{T}$ cells, limited chronic immune activation, and altered mucosal immunity. It is probable that these animals have achieved a unique balance between $\mathrm{T}$-cell renewal and proliferation and loss through activation-induced apoptosis, and virusinduced cell death. A clearer understanding of the mechanisms underlying the lack of disease progression in natural hosts for SIV infection should therefore yield insights into the pathogenesis of AIDS and may inform vaccine design.
\end{abstract}

$T^{\mathrm{h}}$ he simian immunodeficiency viruses (SIVs) are a genetically diverse group of viruses that naturally infect a wide range of African nonhuman primates and are the source of the human immunodeficiency viruses (HIV-1 and HIV-2). The origins of HIV-1 and HIV-2, as well as the SIVcpz and SIVgor strains, are discussed in greater detail in Sharp and Hahn (2011). SIVs first came to the attention of AIDS researchers with the occurrence of immunodeficiency in macaques in the California, New England, and Washington primate centers
(Apetrei et al. 2005). Almost simultaneously, transfer of tissues from sooty mangabeys to macaques resulted in a similar disease at the Tulane Primate Center (Murphey-Corb et al. 1986). The virus isolated from these macaques originated from sooty mangabey monkeys, either by experimental infection at Tulane or through cohousing of African and Asian monkeys earlier in the history of the primate centers (Apetrei et al. 2005). This event represented the birth of a new animal model for HIV infection based on the use of SIVmac and SIVsmm

Editors: Frederic D. Bushman, Gary J. Nabel, and Ronald Swanstrom

Additional Perspectives on HIV available at www.perspectivesinmedicine.org

Copyright (C) 2012 Cold Spring Harbor Laboratory Press; all rights reserved; doi: 10.1101/cshperspect.a007153

Cite this article as Cold Spring Harb Perspect Med 2012;2:a007153 
N.R. Klatt et al.

infection of rhesus macaques (Johnson and Hirsch 1992). Subsequent studies have determined that SIV infection of macaques, although more rapid than HIV infection in humans, is remarkably similar in terms of pathogenesis, and the model has been used extensively for vaccine development (Haigwood 2009). However, the use of the sooty mangabey-derived SIV as an experimental macaque model for AIDS is only a small aspect of the overall scientific interest in the SIV infection of natural African host species. First, these primate viruses are the source of the HIV-1 (cross-species transmission of SIVcpz) and HIV-2 (cross-species transmission of SIVsmm) epidemics in humans (Sharp and Hahn 2010). Second, these animals present a fascinating enigma: lack of progression to AIDS in the face of active viral replication (Hirsch 2004; Paiardini et al. 2009a; Pandrea and Apetrei 2010). It is hoped that the study of the mechanism(s) underlying their resistance to AIDS will help us understanding the pathogenesis of HIV in humans and to design vaccine and therapeutic strategies (Sodora et al. 2009). This article will focus on the natural hosts of SIVs and their viruses and the lessons they teach us about the pathogenesis of AIDS.

\section{THE PRIMATE LENTIVIRUSES}

Origins and Phylogeny of SIVs

There is a wide variety of SIVs in African nonhuman primates, although only a fraction of them have been molecularly characterized (see Table 1). To date, serological evidence of SIV infection has been reported in 36 different primate species, and partial or full-length viral sequences have been characterized from 30 of these (Apetrei et al. 2004). Primate lentiviruses have been detected in most of the African monkeys of the genus Cercopithecus, African green monkeys (Chlorocebus), mandrills and drills (Mandrillus), the mangabeys (Cercocebus), a variety of colobus monkeys (Colobus, Pilocol$b u s)$, and within the great apes, two subspecies of chimpanzees (Pan) and gorillas (Gorilla) (Table 1). However, interestingly, infection of Asian monkeys such as macaques (genus
Macaca) and the Asian great apes, orangutans, has not been detected in the wild. This restriction of primate lentiviruses to African monkeys suggests that this is an ancient virus that has coevolved with its primate host. The observation of similar viruses in related species such as the multiple species of African green monkeys (AGMs) that are infected, despite geographic separation, suggests that the ancestor of the current day SIVs may date back to the time of phylogenetic divergence and geographical separation of African and Asian monkeys. A conservative estimate of the age of natural SIV infections based on the phylogeny of SIVs isolated from nonhuman primates at the Bioko island places these infections at least 32,000 years ago, although less conservative analysis suggests a much longer time (Worobey et al. 2010). In contrast, HIV-1 and HIV-2 infections of humans represent relatively recent introductions into human populations by cross-species transmission (Sharp and Hahn 2010).

As detailed in Table 1 and Figure 1, there are at least seven distinct lineages of primate lentiviruses: (1) SIVsm from sooty mangabeys (Hirsch et al. 1989), including HIV-2; (2) SIVagm from the four different species of AGMs (Allan et al. 1991; Hirsch 2004); (3) SIV from monkeys of the genus Cercopithecus, commonly called guenons (e.g., SIVgsn, SIVdeb, SIVmus) (Courgnaud et al. 2002, 2003); (4) SIVcpz from two species of chimpanzees (Keele et al. 2006) and SIVgor from gorillas; (5) SIVlho and SIVsun from the related L'Hoest and suntailed monkeys (Beer et al. 1999, 2000); (6) SIVcol from black and white colobus monkeys (Courgnaud et al. 2001); and (7) SIVrcm from red capped mangabeys (Beer et al. 2001) and SIVmnd and drl from mandrills and drill monkeys (Clewley et al. 1998; Hu et al. 2003). Each of the various lineages are approximately equidistant from any other lineage, sharing $40 \%-50 \%$ identity in the most conserved Gag and Pol proteins (Hirsch et al. 1995a). The phylogenetic relationship between many of these various SIVs, with distinct species-specific lineages, is shown in Figure 1. The primate lentiviruses all share a common genomic organization encoding the structural and enzymatic proteins Gag, Pol, 
Nonpathogenic Simian Immunodeficiency Virus Infections

Table 1. Natural host species harboring simian immunodeficiency viruses (SIVs)

\begin{tabular}{|c|c|c|c|}
\hline Genus & Common name & Species & SIV \\
\hline Pan & Chimpanzees & $\begin{array}{l}\text { troglodytes troglodytes } \\
\text { troglodytes schweinfurthi }\end{array}$ & $\begin{array}{l}\text { SIVcpzPtt } \\
\text { SIVcpzPts }\end{array}$ \\
\hline Gorilla & Gorilla & gorilla & SIVgor \\
\hline \multirow[t]{2}{*}{ Cercocebus } & Sooty mangabey & atys & SIVsmm \\
\hline & Redcapped mangabey & torquatus & SIVrcm \\
\hline \multirow[t]{2}{*}{ Mandrillus } & Mandrill & $\operatorname{sphin} x$ & SIVmnd-1, mnd-2 \\
\hline & Drill & leucophaeus & SIVdrl \\
\hline Miopithecus & Talapoin & talapoin & SIVtal \\
\hline Colobus & Black and white colobus & guerza & SIVcol \\
\hline Procolobus & Olive colobus & verus & SIVolc \\
\hline Pilocolobus & Western red colobus & badius & SIVwrc \\
\hline \multirow[t]{5}{*}{ Chlorocebus } & African green monkeys & & \\
\hline & Sabaeus & sabaeus & SIVagmSab \\
\hline & Vervet & pygerythrus & SIVagmVer \\
\hline & Tantalus & tantalus & SIVagmTan \\
\hline & Grivet & aethiops & SIVagmGri \\
\hline \multirow[t]{13}{*}{ Cercopithecus } & The guenons & & \\
\hline & Greater spot-nosed & nictitans & SIVgsn \\
\hline & Blue monkey & mitis & SIVblu \\
\hline & Mona monkey & mona & SIVmon \\
\hline & Dents' monkey & denti & SIVden \\
\hline & Moustached monkey & cephus & SIVmus \\
\hline & Red-eared monkey & erythrotis & SIVery \\
\hline & Redtailed monkey & ascanius & SIVasc \\
\hline & DeBrazza & neglectus & SIVdeb \\
\hline & Sykes monkey & albogularis & SIVsyk \\
\hline & L'Hoests monkey & l'hoesti & SIVlho \\
\hline & Suntailed monkey & solatus & SIVsun \\
\hline & Preussis monkey & preussi & SIVpre \\
\hline
\end{tabular}

and Env but also a variety of accessory proteins. All SIV and HIV strains share open reading frames for tat, rev, vif, vpr, and nef genes. However, the $v p u$ gene is unique to HIV-1, SIVcpz, and a variety of SIV strains from Cercopithecus monkeys including SIVgsn (greater spot nosed monkey) (Courgnaud et al. 2003), consistent with an ancestral relationship between these viruses. In contrast, the $v p x$ gene is unique to SIVs from mangabeys, SIVsmm and SIVrcm; in these two viruses, some of the various functions of the $v p r$ gene have been segregated to $v p x$. Recent studies suggest that some of the functions attributed to $v p u$ gene were acquired by the nef or the env genes in viruses that lack $v p u$ (Sauter et al. 2009) suggesting that they played a role in overcoming intrinsic host restriction factors on cross-species transmission as discussed in Sharp and Hahn (2010).

This family of primate lentiviruses has also been the source of two separate epidemics in humans. HIV-1 arose from multiple cross-species transmissions events with HIV-1 Groups $\mathrm{M}$ and $\mathrm{N}$ arising from SIVcpzPtt and SIVcpzPts, and HIV-1 Group O from SIVgor (Fig. 1, red lines) (reviewed in Sharp and Hahn 2010). Similarly, SIVsmm (Hirsch et al. 1989) was the source of the HIV-2 epidemic in West Africa (Fig. 1, red lines). Although SIVs are generally not pathogenic in their natural host species, the infection of humans by these animals, and evolution as HIV-1 and -2 , was associated with the acquisition of virulence. 
N.R. Klatt et al.

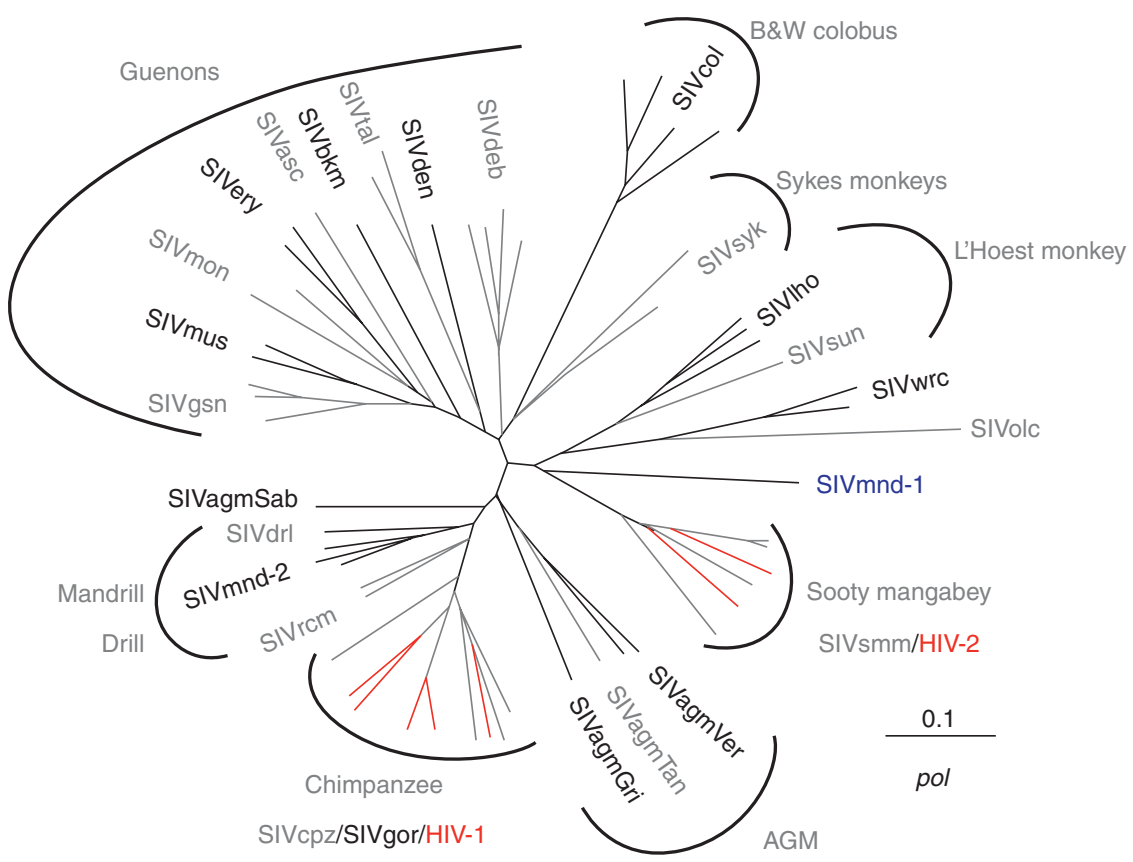

Figure 1. SIV and HIV lineages. Phylogenetic tree of a region of polymerase showing the relationship between the various primate lentiviruses. HIV strains are shown in red. The nonhuman primate natural hosts for are shown for each cluster. (Adapted from Peeters et al. 2008 and reprinted with permission from EDP Science (C) 2008.)

Epidemiology, Cross-Species Transmission, and Recombination

Serologic surveys and evaluation of bushmeat in Africa reveal that infection of nonhuman primates is widespread, although the prevalence may vary, depending on species and geographic location (Aghokeng et al. 2006, 2010). SIV infection has been detected in nearly all species of African nonhuman primates with the possible exception of one species of chimpanzee (Pan troglodytes vellerosus), baboons, and patas monkeys. In some species of monkeys, there is serological evidence of infection, but viruses have not yet been isolated or characterized. The prevalence of infection increases with age, with fairly uniform lack of infection in infants and juveniles suggesting that sexual routes as well as aggression may play a role in transmission. Furthermore, mother to infant transmission appears to be somewhat rare based on the lack of infection in infants and juveniles. This notion is also supported by studies of the colony of sooty mangabeys housed at the Yerkes primate center, in which only $\sim 5 \%$ of infants born to SIV-infected mothers appear to have contracted the infection vertically (Chahroudi et al. 2011). However, the route of transmission in wild populations has not been clearly defined.

SIVs generally appear to be species-specific, and with each species showing only one virus except for mandrills that are infected with two viruses (SIVmnd-1 and SIVmnd-2). This pattern is consistent with coevolution during the speciation and migration of the different primate species throughout Africa. For example, SIVagm strains are present within all species of AGM (vervet, grivet, tantalus, and sabaeus) throughout sub-Saharan Africa, but each of the species harbor a distinct, but related virus (70\% identity). In at least two cases, the species of AGM have been geographically isolated from one another for thousands of years, ruling out contemporaneous spread of the virus (Muller and Barre-Sinoussi 2003; Hirsch 2004). 
However, with more extensive characterization, the picture has becomes increasingly complex with evidence of multiple cross-species transmissions and recombination events. There is evidence for present-day natural transmission occurring in the wild, for example SIVagm infection of baboons and patas monkeys (Jin et al. 1994a; Bibollet-Ruche et al. 1996). However, there is also evidence of a long history of cross-species transmission, coinfections, and apparent recombination. Many of the SIV strains appear to be recombinant and often the parental strains are difficult to define because of genetic divergence from representative strains. The most notable recombinant is HIV-1 and its ancestor SIVcpz. SIVcpz appears to be a recombinant between ancestral viruses that gave rise to SIVrcm from red-capped mangabeys, and the clade of viruses found that infect species of Cercopithecus monkeys or guenons that includes greater spot-nosed, mona, and mustached monkeys (Bailes et al. 2003; Courgnaud et al. 2003). Other obvious recombinants are (1) SIVagmSab from the West African sabaeus species of AGM that is a recombinant of an ancestral forms of SIVagm and SIVrcm (Jin et al. 1994b); (2) SIVrcm from red capped mangabeys (Beer et al. 2001); and (3) SIVdrl and SIVmnd-2 from drills and mandrills, respectively, that are recombinants between SIVrcm and SIVmnd-1 (Hu et al. 2003). These latter viruses share a common breakpoint, suggesting a common origin and another example of cross-species transmission. Presumably, there has been a long history of cross-species transmission events and recombination within the primate lentiviruses. However, it is still evident from the species specificity of many of these strains that these viruses are ancient and have coevolved with their host species over long periods of time.

\section{PATHOGENESIS STUDIES IN ANIMAL MODELS}

\section{Experimental Animal Models}

Despite the wide range of SIV-infected African nonhuman primates in the wild, there are only three available models for experimental manipulation. Essential elements for such studies are a molecularly characterized SIV strain that can reproduce the kinetics of viral replication seen in natural infection and availability of the correct species from which this virus was initially derived. Animal models that satisfy these criteria are (1) SIVsmm infection of sooty mangabeys (SMs); (2) SIVagm infection of AGMs; and (3) SIVmnd infection of mandrills (Pandrea et al. 2003; Onanga et al. 2006). Two lineages of SIVagm have been evaluated in vivo, SIVagmVer and SIVagmSab from vervet and sabaeus AGM, respectively (Goldstein et al. 2006; Pandrea et al. 2006a,b). Initial studies with SIVagmSab were performed using sabaeus AGMs of African origin but a model has now been established using the same species of AGM of Caribbean origin, as these animals were imported from Africa more than 300 years earlier and are more readily available for experimental manipulations (Pandrea et al. 2006b). Initial studies of various strains of SIVagm in different species of AGMs revealed that these viruses are adapted for their specific host species (Goldstein et al. 2006). Thus, SIVagmVer strains are restricted in terms of replication in sabaeus AGMs relative to replication in their matched host, vervet AGMs. Because of cost and ethical issues, SIVcpz infection of chimpanzees has only been studied on a small scale or in terms of its impact in wild, habituated chimpanzee populations (Keele et al. 2009) and is discussed in more detail in article by Hahn and Sharp (2011). Infection of mandrills with SIVmnd has also been studied to a limited degree, because of restricted availability of these animals in captivity (Pandrea et al. 2003; Onanga et al. 2006). Therefore, much of what we know about natural hosts has been gleaned from studies of SMs and AGMs.

\section{General Characteristics of Natural Infection}

The lack of virulence of SIV isolates for their homologous natural host species is intriguing when contrasted with their effect in Asian macaques, and with the typically pathogenic effect of HIV-1 in humans. Natural SIV hosts, such as SMs infected with SIVsmm or AGMs infected 
N.R. Klatt et al.

with SIVagm, generally show no evidence of immunodeficiency. There have been sporadic reports of the development of immunodeficiency, as defined by opportunistic infection or neoplasms normally associated with AIDS. Indeed, $\mathrm{CD}^{+}{ }^{+}$T-cell depletion was observed in one naturally infected mandrill, and immunodeficiency was observed in a SM that had been naturally SIV-infected for more than 18 years (Ling et al. 2004; Pandrea et al. 2009). AIDS has also been observed in at least one chimpanzee inoculated with HIV-1 and progressive infection seen in a subset of HIVinfected chimpanzees (Novembre et al. 1997; O'Neil et al. 2000). Although HIV-1 is only a close relative of SIVcpz, this study suggests that these African primates are not immune to the pathogenic effects of primate lentiviruses under specific circumstances. Indeed, recent studies in wild habituated chimpanzee populations show a significantly greater mortality rate associated with SIVcpz infection (Keele et al. 2009). This is in agreement with the idea that SIVcpz is perhaps less adapted to chimpanzees than SIV in such hosts as SMs, consistent with a more recent introduction into chimpanzees from the monkeys on which they prey. The conclusion is that SIV infection of most natural host species is generally asymptomatic within the time frame of the lifespan of the animal. This lack of pathogenicity has been postulated to be the result of an evolutionary adaptation that, in AGMs and SMs, allows for a mutual coexistence between the host and the virus.

Despite their general lack of pathogenicity in their matched host species, SIVs clearly do not not lack the intrinsic potential to cause AIDS, revealed by the either accidental or experimental introduction of SIVsmm into rhesus macaques (RMs) (Apetrei et al. 2005). In addition, experimental infection of macaque species with SIVsmm, SIVagm, and SIVlho results in a syndrome remarkably similar in pathogenesis of AIDS in humans. Interestingly, uncloned/ unpassaged SIVsmm in RMs results in levels of virus replication that are lower than in SIV-infected SMs (Bosinger et al. 2009); however, when SIVsmm becomes adapted to RM cells through in vitro and/or in vivo passage, the level of virus replication become even higher than in SMs (Johnson et al. 1990; Hirsch et al. 1995b). In the case of SIVagm and SIVlho, infection of pigtail macaques (Macaca nemstrina) was required to achieve efficient replication and subsequent disease (Hirsch et al. 1995b; Beer et al. 2005). The majority of pathogenesis and vaccine studies have focused on SIVmac infection of RMs because of its more uniform course of infection. Interestingly, recent studies revealed that allelic variation in the rhesus macaque TRIM $5 \alpha$ gene results in differences in susceptibility to infection and viral replication in the early stages of cross-species transmission of SIVsmm and that emergence of pathogenic SIVmac in RMs required adaptations in the viral capsid protein (CA) to overcome suppression by two distinct types of TRIM5 $\alpha$ allele (Kirmaier et al. 2010). Presumably similar types of adaptations occurred for both HIV-1 and HIV-2.

SIV infections of SMs, AGMs, and mandrills share many similar features with pathogenic infections such as SIVmac infection of macaques and HIV infection of humans (Johnson and Hirsch 1991; Paiardini et al. 2009b). The general features of SIV infection of AGM and SM are compared with pathogenic infection in with differences highlighted (Table 2). Common features include the kinetics of primary viremia with robust peak viremia and persistence of viremia into the chronic phase of infection in both models (Pandrea et al. 2006a). Infection is associated with the development of adaptive and innate immune responses that are similar or lower in kinetics and magnitude, and fail to control virus replication. Based on the rapidity of viral clearance following treatment with antiviral drugs, SIV infection targets cells whose lifespan is short (i.e., 1-2 d) (Gordon et al. 2008; Pandrea et al. 2008a) and even acute depletion/loss of mucosal CD $4^{+} \mathrm{T}$ cells, once thought to be pathognomonic for pathogenic primate lentivirus infections, is observed in both models. The most obvious difference is the clinical course of disease in natural hosts, which is typically nonprogressive. Other distinguishing features of natural host infections are (1) the maintenance of peripheral $\mathrm{CD} 4{ }^{+} \mathrm{T}$ cells 
Nonpathogenic Simian Immunodeficiency Virus Infections

Table 2. Comparisons of the characteristics of primate lentivirus infection of natural SIV hosts versus macaques and humans

\begin{tabular}{|c|c|c|}
\hline \multirow[b]{2}{*}{ Characteristics } & \multicolumn{2}{|c|}{ Host species } \\
\hline & $\begin{array}{l}\text { Sooty mangabeys and } \\
\text { African green monkeys }\end{array}$ & Humans and Asian macaques \\
\hline \multirow[t]{5}{*}{ Clinical outcome } & $\begin{array}{l}\text { Depletion of peripheral } \mathrm{CD}^{+} \mathrm{T} \text { cells } \\
\text { rare }\end{array}$ & Progressive depletion of $\mathrm{CD} 4^{+} \mathrm{T}$ cells \\
\hline & Progression to AIDS is very rare. & Progression to AIDS is common. \\
\hline & Survival for up to $20-30 \mathrm{yr}$ & Median survival $1.5 \mathrm{yr}$ \\
\hline & Generally no evidence of AIDS & $\begin{array}{l}\text { Opportunistic infections, neoplasia, } \\
\text { encephalitis }\end{array}$ \\
\hline & Vertical transmission is rare. & Vertical transmission is more common. \\
\hline \multirow[t]{4}{*}{ Viremia } & $\begin{array}{l}\text { High peak viremia in } 1-2 \mathrm{wk} \\
\quad\left(10^{6}-10^{8} / \mathrm{mL}\right)\end{array}$ & $\begin{array}{l}\text { High peak viremia in } 1-2 \mathrm{wk} \\
\quad\left(10^{6}-10^{8} / \mathrm{mL}\right)\end{array}$ \\
\hline & Post-peak decline of viral load & Variable post peak decline in viral load \\
\hline & $\begin{array}{l}\text { High to moderate set point virus load } \\
\qquad\left(10^{3}-10^{6} / \mathrm{mL}\right)\end{array}$ & $\begin{array}{l}\text { High set point of virus replication } \\
\qquad\left(10^{5}-10^{8} / \mathrm{mL}\right)\end{array}$ \\
\hline & Stable setpoint & Increasing viral load over time \\
\hline \multirow[t]{8}{*}{ Immune responses } & Adaptive immune responses & Adaptive immune responses \\
\hline & Marked acute type I interferon response & Marked acute type I interferon response \\
\hline & Resolution of type I interferon responses & Persistence of type I interferon responses \\
\hline & $\begin{array}{l}\text { Variable bystander T-cell activation and } \\
\text { apoptosis }\end{array}$ & $\begin{array}{l}\text { High levels of bystander T-cell activation } \\
\text { and apoptosis }\end{array}$ \\
\hline & $\begin{array}{l}\text { Establishment of an anti-inflammatory } \\
\text { milieu }\end{array}$ & $\begin{array}{l}\text { Establishment of a proinflammatory } \\
\text { milieu }\end{array}$ \\
\hline & $\begin{array}{l}\text { Limited immune activation and T-cell } \\
\text { apoptosis }\end{array}$ & $\begin{array}{l}\text { Generalized immune activation and } \\
\text { significant T-cell apoptosis }\end{array}$ \\
\hline & Preservation of mucosal TH17 cells & Preferential loss of mucosal TH17 cells \\
\hline & Absence of microbial translocation & Microbial translocation is prominent. \\
\hline \multirow[t]{4}{*}{ Target cells } & Short-lived, activated CD $4^{+} \mathrm{T}$ cells & Short-lived, activated $\mathrm{CD} 4^{+} \mathrm{T}$ cells \\
\hline & Early depletion of mucosal CD $4^{+} \mathrm{T}$ cells & Early depletion of mucosal CD $4^{+} \mathrm{T}$ cells \\
\hline & $\begin{array}{l}\text { Healthy CD } 4^{+} \text {T-cell counts in most } \\
\text { animals }\end{array}$ & $\begin{array}{l}\text { Progressive depletion of circulating and } \\
\text { mucosal CD } 4^{+} \mathrm{T} \text { cells }\end{array}$ \\
\hline & $\begin{array}{l}\text { CD4 depletion is not associated with } \\
\text { AIDS. }\end{array}$ & $\begin{array}{l}\text { CD4 depletion of }<100 / \mu \mathrm{L} \text { is } \\
\text { associated with AIDS. }\end{array}$ \\
\hline
\end{tabular}

levels in the majority of animals; (2) the lack of chronic immune activation following resolution of primary infection; (3) the absence of microbial translocation; and (4) the preferential sparing of $\mathrm{CD}^{+}{ }^{+}$central memory $\mathrm{T}$ cells from infection.

\section{Targets Cells for SIV Replication}

Similar to pathogenic models of $\mathrm{HIV} / \mathrm{SIV}$ infection, SIV expression is primarily observed in lymphoid tissues and the gastrointestinal tract by polymerase chain reaction or in situ hybridization (Goldstein et al. 2006). The vast majority (i.e., $>90 \%$ ) of SIVsmm replication in naturally SIV-infected SMs and AGMs occurs in short-lived cells (Perelson et al. 1993; Ho et al. 1995; Wei et al. 1995; Nowak et al. 1997), suggesting that activated $\mathrm{CD} 4^{+} \mathrm{T}$ cells are the major site for viral replication (Gordon et al. 2008; Pandrea et al. 2008a). This finding was shown by treating SMs and AGMs with reverse transcriptase inhibitors, and the lifespan of productively infected cells was calculated based on the slope of the decline of SIV plasma viremia after initiation of ART using a widely accepted mathematical model (Perelson et al. 1997; Gordon et al. 2008; Pandrea et al. 2008a). In 
N.R. Klatt et al.

addition, in situ hybridization studies have shown that SIVsmm and SIVagm colocalizes with $\mathrm{CD}^{+}$lymphocytes in lymph nodes and mucosal tissues of SMs and AGMs, respectively (Pandrea et al. 2008a; Sodora et al. 2009). Further evidence that SIVsmm infected activated $\mathrm{CD}^{+} \mathrm{T}$ cells in vivo was shown by depletion of $\mathrm{CD} 4^{+} \mathrm{T}$ cells in SIV-infected SMs; the subsequent levels of viremia correlated directly with the number of activated $\mathrm{CD} 4^{+} \mathrm{T}$ cells (Klatt et al. 2008). The rapid depletion of mucosal $\mathrm{CD} 4{ }^{+} \mathrm{T}$ cells during acute SIVsmm and SIVagm infection also suggested that $\mathrm{CD} 4^{+} \mathrm{T}$ cells are the main targets of SIV replication in SM and AGM (Gordon et al. 2007; Pandrea et al. 2007a). However, despite destruction of mucosal $\mathrm{CD} 4^{+} \mathrm{T}$ cells during acute infection and concomitant development of chronic viremia, these animals maintain relatively normal mucosal immune function, with preserved levels of Th17 cells and a lack of microbial translocation (Brenchley et al. 2006, 2008; Sumpter et al. 2007). Although maintenance of peripheral $\mathrm{CD} 4^{+} \mathrm{T}$ cells in natural hosts is a striking feature of natural SIV infection, this model also shows that loss of $\mathrm{CD}^{+} \mathrm{T}$ cells alone is not sufficient to cause AIDS (Kosub et al. 2008). Indeed, naturally and experimentally SIV-infected SMs exist that are depleted of peripheral $\mathrm{CD}^{+}{ }^{+} \mathrm{T}$ cells during infection, but remain AIDS-free (Sumpter et al. 2007; Milush et al. 2007). Furthermore, experimental CD4 ${ }^{+}$ lymphocyte depletion in SIV-infected SMs does not result in AIDS (Klatt et al. 2008), nor does $\mathrm{CD} 4^{+}$depletion in either uninfected SMs or RMs result in an AIDS-like phenomenon (Engram et al. 2010). Thus, preservation of peripheral $\mathrm{CD}^{+}{ }^{+} \mathrm{T}$ cells during natural SIV infection does not by itself explain the lack of disease progression in natural hosts.

\section{Adaptive Immune Responses}

The fact that natural hosts maintain high viral load (Rey-Cuille et al. 1998; Chakrabarti et al. 2000; Silvestri et al. 2003) indicates that the disease resistance of these animals is unlikely to be because of particularly effective SIVspecific immune responses. This hypothesis is supported by the observations of lower levels of virus-specific T-cell responses in SIVinfected SMs than HIV-infected individuals (Dunham et al. 2006). In addition, depletion of $\mathrm{CD}^{+} \mathrm{T}$ cells results in minimal increase in virus replication in either chronically SIVinfected SMs or during primary infection of AGMs (Schmitz et al. 1999; Barry et al. 2007). In contrast, $\mathrm{CD}^{+}$lymphocyte depletion in SIV-infected rhesus macaques or pigtail macaques results in increased virus replication and rapid disease progression (Schmitz et al. 1999, 2009; Klatt et al. 2010). Furthermore, lack of disease progression cannot be accounted for by humoral responses. Depletion of CD20 ${ }^{+}$ $B$ cells in AGMs significantly delays seroconversion but does not result in significant changes in viremia (Schmitz et al. 1999; Gaufin et al. 2009). Moreover, autologous neutralizing antibody levels in SIV infection of SMs are much lower than those observed in HIV-infected humans (Li et al. 2010). Thus, immune control during chronic SIV infection of natural hosts likely does not account for the nonpathogenic nature of the infection.

\section{Innate Immune Responses}

Despite the lack of immune control of SIV replication in natural hosts, there is a rapid and robust innate immune response to SIV during acute infection. Similar to pathogenic SIV infection (Table 2), acute SIV infection of SMs and AGMs results in a rapid increase in proliferating T cells (Bosinger et al. 2009; Jacquelin et al. 2009). Activation of an innate immune response was observed as an induction and massive up-regulation of interferon responsive genes measured by gene expression during acute SIV infection of both SMs and AGMs (Bosinger et al. 2009; Jacquelin et al. 2009; Lederer et al. 2009). This is associated with the production of type I interferons by plasmacytoid dendritic cells ( $\mathrm{pDCs}$ ) as measured by immunohistochemical staining in tissues during acute SIVsmm infection (Harris et al. 2010). Moreover, during acute SIV infection, in vitro production of type I interferons by SIV-stimulated pDCs was enhanced in AGMs 
compared to RMs (Jacquelin et al. 2009). However, in stark contrast to pathogenic SIV infection of RMs or HIV infection of humans, this robust innate immune response to the virus is rapidly attenuated after acute SIV infection of both SMs and AGMs (Bosinger et al. 2009; Jacquelin et al. 2009; Harris et al. 2010). Consistent with this, a similar phenomena is observed in a minor subset of HIV-infected individuals who are highly viremic but maintain high $\mathrm{CD}^{+}{ }^{+} \mathrm{T}$ cell counts (Rotger et al. 2011). The genetic profile of $\mathrm{T}$ cells isolated from these viremic nonprogressors is similar to that of natural hosts, and, furthermore, interferonstimulated gene expression was decreased compared to progressive infection, but similar to chronically infected natural hosts (Rotger et al. 2011). Indeed, many reports indicate that a striking and consistent feature of SIV infection of natural hosts is the lack of chronic, generalized immune activation (Silvestri et al. 2003; Paiardini et al. 2006; Sumpter et al. 2007), which is one of the major correlates of disease progression in pathogenic models (McCune 2001; Picker 2006; Fauci 2008).

\section{Chronic Immune Activation and Microbial Translocation}

Systemic immune activation, characterized by increased cell proliferation, high rates of lymphocyte apoptosis, cell cycle dysregulation, and increased levels of proinflammatory cytokines (Paiardini et al. 2004, 2006; Hurtrel et al. 2005; Hunt et al. 2008) is a very strong predictor of disease progression during pathogenic HIV/ SIV infections. Massive infection of $\mathrm{CD}^{+}{ }^{+} \mathrm{T}$ cells in MALT early in HIV/SIV infections is proposed to be associated with breakdown of mucosal integrity, which allows microbial products to translocate from the lumen of the gastrointestinal (GI) tract into peripheral circulation (Brenchley et al. 2006). Translocation of microbial products during pathogenic HIV/ SIV infections, can be shown by an increase in plasma lipopolysacharide (LPS) and bacterial DNA levels and is significantly correlated with systemic immune activation (Brenchley et al. 2006). A consistent feature of natural infection is the absence of generalized chronic immune activation that is characteristically associated with disease progression in pathogenic SIV and HIV infection. Indeed, SIV-infected SMs have low levels of immune activation, T-cell turnover and cell cycle perturbation as compared to SIV-infected RMs or HIV-infected humans, and more comparable levels in uninfected animals (Silvestri et al. 2003; Paiardini et al. 2006; Sumpter et al. 2007). Moreover, SIV infection of natural hosts does not result in microbial translocation, as shown by lack of LPS or sCD14 in the plasma of SIV-infected RMs or AGM (Brenchley et al. 2006; Pandrea et al. 2007a). Furthermore, experimentally induced immune activation with LPS in natural hosts results in significantly increased virus replication and $\mathrm{CD} 4^{+}$T-cell depletion (Pandrea et al. 2008b), which indicates that lack of chronic, systemic immune activation, and microbial translocation may play a role in the lack of disease progression observed in natural hosts.

\section{POTENTIAL MECHANISMS UNDERLYING LACK OF DISEASE PROGRESSION}

The key to understanding the benign nature of SIV infection in natural hosts likely lies in understanding the differences between pathogenic and nonpathogenic infections. The most notable differences between SIV-infected natural hosts and SIV-infected macaques and HIV-infected humans are the lack of $\mathrm{CD} 4^{+}{ }^{-}$-cell depletion and attenuation of immune activation.

\section{Attenuated Chronic Immune Activation}

As mentioned above, natural hosts have the ability to dampen acute innate immune responses to SIV after a few weeks of infection. This feature contrasts with pathogenic SIV and HIV infections in which immune activation persists throughout the course of infection (Fig. 2). The precise mechanisms underlying resolution of acute immune activation in SIV-infected SMs and AGMs remain poorly understood and are likely quite complex. Several hypotheses have been proposed, including (1) rapid up-regulation of the membrane 
N.R. Klatt et al.

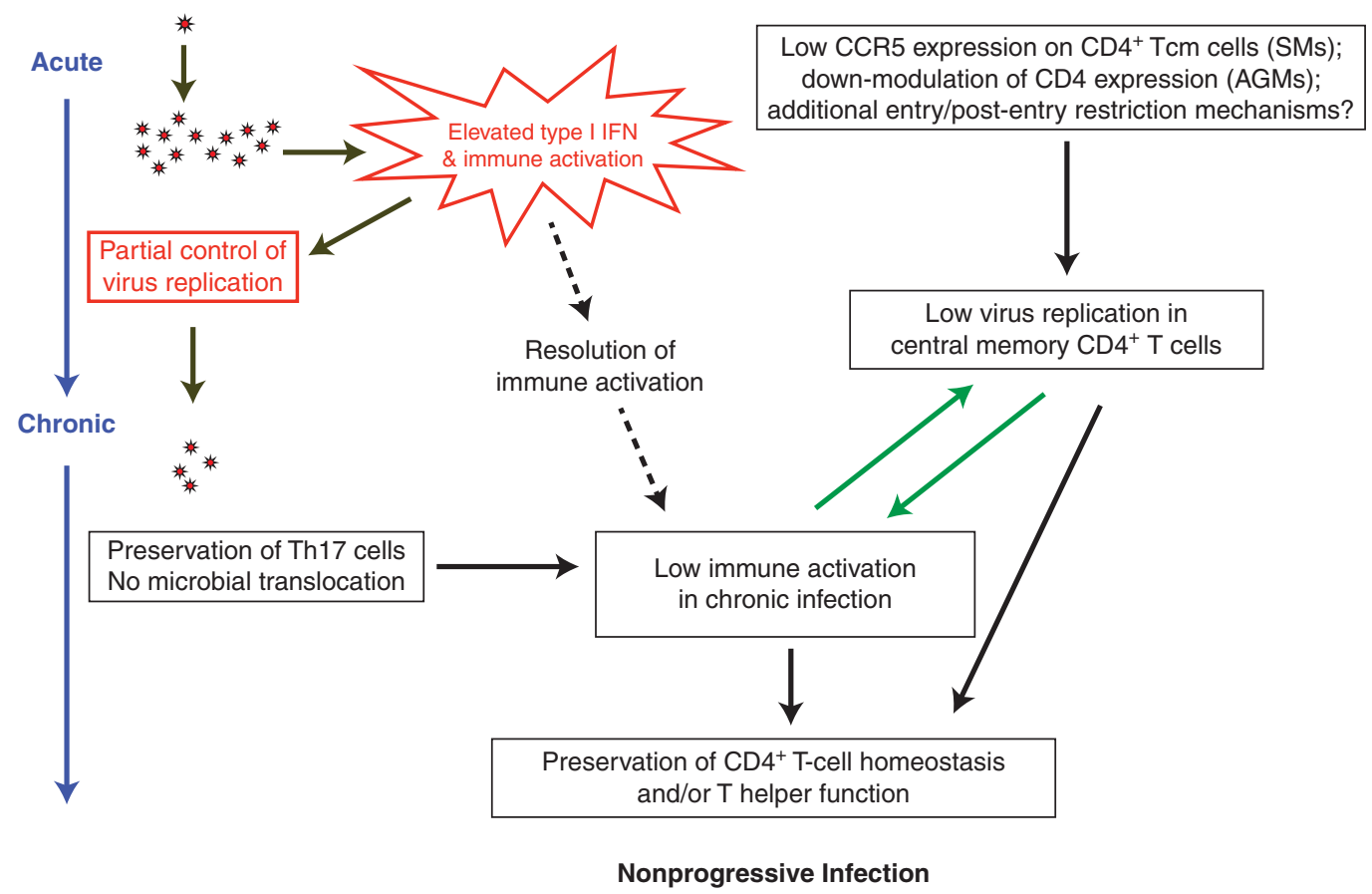

Figure 2. Pathophysiology of natural SIV infections.

receptor programmed death 1 (PD-1); (2) lack of up-regulation of genes such as TRAIL (tumor necrosis factor-related apoptosis-inducing ligand/Apo-2 ligand) and other associated death receptors that trigger apoptosis after pathogenic HIV/SIV infections of human and RMs (Kim et al. 2007); (3) early enhanced Treg responses; (4) reduced response to TLR ligands by pDCs during chronic infection (Mandl et al. 2008); and (5) the ability of Nef alleles to down-modulate the CD3-TCR complex from the surface of infected cells. Additional studies addressing genetic regulation of immune activation after acute SIV infection of natural hosts compared to nonnatural hosts will be crucial in determining a precise mechanism in which natural hosts resolve acute immune activation.

\section{Lack of Microbial Translocation}

One potentially important mechanism that underlies the lack of immune activation in SIV-infected natural hosts is absence of significant microbial translocation in these animals (Fig. 2). During SIV infection of RMs, damage to the mucosal barrier of the GI tract is associated with microbial translocation and ensuing immune activation (Estes et al. 2010). In natural infection, preservation of mucosal immune function and of the tight epithelial barrier of the GI tract appears to prevent microbial translocation from occurring. The absence of microbial translocation is associated with preservation of cell subsets integral to mucosal health, including $\gamma-\delta \mathrm{T}$ cells and Th17 cells. $\gamma-\delta \mathrm{T}$ cells, which are important for mucosal immunity and response to bacterial antigens, are dysregulated during HIV infection but preserved during SIV infection of SMs (Kosub et al. 2008). Th17 cells are specialized $\mathrm{CD} 4^{+} \mathrm{T}$ cells that produce IL-17 as a signature cytokine in response to bacterial and fungal antigens, that are preferentially depleted from mucosal tissues during pathogenic HIV/SIV infections (Brenchley et al. 2008; Klatt and Brenchley 2010) but are maintained in natural hosts (Klatt and Brenchley 2010). Thus, despite loss of mucosal CD ${ }^{+} \mathrm{T}$ cells 
after SIV infection of natural hosts, particular subsets important for mucosal immunity such as $\gamma-\delta$ and Th17 cells are maintained. The retention of such cells may underlie the lack of damage to the GI tract and ensuing microbial translocation and immune activation in natural SIV hosts (Brenchley et al. 2008; Favre et al. 2009; Paiardini 2010).

\section{Target Cell Restriction}

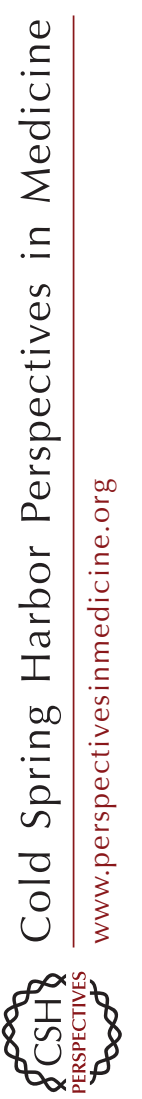

Low levels of mucosal CCR $5^{+} \mathrm{CD} 4^{+} \mathrm{T}$-cell targets appears to be a common characteristic of natural hosts (Pandrea et al. 2007b). Indeed, recent studies suggest additional mechanisms used by these hosts to restrict access of SIV to crucial central memory (TCM) $\mathrm{CD} 4^{+} \mathrm{T}$ cells, "the target restriction" hypothesis (Fig. 2) (Brenchley et al. 2010). CD4 ${ }^{+}$TCMs are a subset of antigen-experienced $\mathrm{T}$ cells that serve as a self-renewing source, whereas $\mathrm{CD}^{+}$effector memory (TEM) are more "expendable" and activated than $\mathrm{CD}^{+}{ }^{+} \mathrm{TCM}$ cells, and produce the most virus (Grossman et al. 2006). These cells play a central role in AIDS pathogenesis as shown in the pathogenic model of SIV infection of rhesus macaques (RMs), in which depletion of $\mathrm{CD}^{+}{ }^{+}$TCM cells is crucial for progression to AIDS and, conversely, preservation of these cells is a correlate of vaccine efficacy (Letvin et al. 2006; Mattapallil et al. 2006; Okoye et al. 2007). Protection of CD ${ }^{+}$TCM in natural SIV hosts appears to occur, at least in part, at the entry level. In AGMs, protection of memory $\mathrm{CD} 4^{+} \mathrm{T}$ cells from SIVagm infection is achieved through down-regulation of the expression of the CD4 molecule as these cells enter the memory pool (Beaumier et al. 2009). AGM "helper" $\mathrm{T}$ cells that have down-modulated CD4 expression maintain functions that are typical of $\mathrm{CD}^{+}{ }^{+} \mathrm{T}$ cells, including production of IL-2 and IL-17, expression of FOX-P3 and CD40 ligand, and restriction by major histocompatibility complex class II molecules (Beaumier et al. 2009). In the case of SIV-infected SMs, expression of CD4 is maintained as these cells enter the memory pool. However, $\mathrm{CD} 4^{+}$ TCMs of SM express significantly lower levels of CCR5 both while resting and when undergoing in vivo and in vitro activation (Pandrea et al. 2007b; Paiardini et al. 2011). Thus, purified $\mathrm{CD}^{+}{ }^{+}$TCM show on average $>10$-fold lower levels of cell-associated SIVDNA when compared to either $\mathrm{CD} 4^{+}$TEM of SMs or $\mathrm{CD}^{+}{ }^{+}$TCM of SIV-infected rhesus macaques, RMs (Paiardini et al. 2011). It is not clear whether this is a common mechanism observed in all natural hosts of SIV because samples are not readily available for this analysis. Although regulation of CCR5 expression is central in determining the level of SIV infection of $\mathrm{CD}^{+}{ }^{+} \mathrm{TCM}$ in SMs, other mechanisms must also play a role. For example, $6 \%$ of SIV-infected SMs are homozygous for a $2 \mathrm{bp}$ deletion in CCR5 $(\Delta 2)$ that abrogates surface expression of CCR5 (Riddick et al. 2010). These animals show $\sim 0.5 \log$ lower viral load than CCR5 wild-type SMs and slightly elevated levels of $\mathrm{CD}^{+}{ }^{+} \mathrm{T}$ cells. In addition, SMs infected with an CXCR4-tropic SIVsmm that depletes most $\mathrm{CD}^{+}$TCM may be protected by $\mathrm{CD}^{+}$ $\mathrm{CD} 4^{-} \mathrm{CD} 8^{-}$cells that produce "helper" cytokines and show a TCM-like phenotype (Milush et al. 2011).

In terms of pathophysiology, sparing of the $\mathrm{CD}^{+}{ }^{+}$TCM subset may limit the homeostatic strain on the pool of $\mathrm{CD} 4^{+}$TCMs and may help preserve a normal total pool of $\mathrm{CD}^{+} \mathrm{T}$ cells that maintains the low level of immune activation observed in natural hosts. Taken together with other mechanisms of attenuated immune activation, including downregulation of acute immune responses, lack of microbial translocation, and preservation of mucosal immune cells, natural hosts have evolved efficient mechanisms by which they remain free of disease after SIV infection.

\section{CONCLUSION}

Although these hypotheses are quite intriguing, more work needs to be performed to ascertain whether the degree to which lack of microbial translocation, low immune activation, and protection of $\mathrm{CD}^{+}{ }^{+} \mathrm{TCM}$ are essential to determine the nonprogressive course of infection observed in natural SIV hosts. Future research goals include the identification of the cellular and 
N.R. Klatt et al.

molecular mechanisms responsible for the rapid down-modulation of the immune activation in natural SIV hosts as well as the discovery of major cellular and viral factors that may protect $\mathrm{CD} 4{ }^{+}$TCM from SIV in natural hosts. Furthermore, a more complete understanding of the pathophysiologic link between microbial translocation, virus replication in $\mathrm{CD} 4{ }^{+} \mathrm{TCM}$ cells and immune activation is needed. Indeed, a more complete understanding of other potential mechanisms by which natural hosts attenuate immune activation would help to define the basis for reduced pathogenicity of these natural infections. Elucidation of how natural hosts prevent microbial translocation will also benefit from a definition of the mechanism of mucosal protection that preserves mucosal barrier function and prevents damage to the gut epithelium and microbial translocation during nonpathogenic SIV infection. Furthermore, an assessment of the degree of pathogenicity in natural and nonnatural hosts of SIV molecular clones that express accessory gene products (i.e., Nef, $\mathrm{Vpu}$, etc.) that have lost specific functions will establish the role of specific viral factors in the pathophysiology of natural SIV infections. Finally, the development of a model in which AIDS is induced in natural hosts by increasing their immune activation and/or expanding their target cell tropism, or, conversely, SIVinfected macaques are rendered AIDS-free by reducing the immune activation in the chronic phase of infection and/or by protecting their $\mathrm{CD}^{+}{ }^{+} \mathrm{TCM}$ resistant from infection would provide substantial insight into HIV infection.

There are clearly major lessons to be learned from the natural hosts of SIV, who have spent thousands of years coevolving with the virus, and in fact it is quite possible that a full understanding of the reasons why HIV causes AIDS in humans will not be possible until the mechanisms by which SIVs do not cause disease in natural hosts are fully clarified. In this view, studies of natural SIV hosts have a tremendous impact in AIDS research as a better understanding of HIV pathogenesis will likely result in novel therapeutic and vaccination strategies to delay or prevent HIV transmission and/or disease progression in humans.

\section{REFERENCES}

* Reference is also in this collection.

Aghokeng AF, Liu W, Bibollet-Ruche F, Loul S, MpoudiNgole E, Laurent C, Mwenda JM, Langat DK, Chege GK, McClure HM, et al. 2006. Widely varying SIV prevalence rates in naturally infected primate species from Cameroon. Virology 345: 174-189.

Aghokeng AF, Ayouba A, Mpoudi-Ngole E, Loul S, Liegeois F, Delaporte E, Peeters M. 2010. Extensive survey on the prevalence and genetic diversity of SIVs in primate bushmeat provides insights into risks for potential new cross-species transmissions. Infect Genet Evol 10: 386-396.

Allan JS, Short M, Taylor ME, Su S, Hirsch VM, Johnson PR, Shaw GM, Hahn BH. 1991. Species-specific diversity among simian immunodeficiency viruses from African green monkeys. J Virol 65: 2816-2828.

Apetrei C, Robertson DL, Marx PA. 2004. The history of SIVS and AIDS: Epidemiology, phylogeny and biology of isolates from naturally SIV infected non-human primates (NHP) in Africa. Front Biosci 9: 225-254.

Apetrei C, Kaur A, Lerche NW, Metzger M, Pandrea I, Hardcastle J, Falkenstein S, Bohm R, Koehler J, Traina-Dorge V, et al. 2005. Molecular epidemiology of simian immunodeficiency virus SIVsm in U.S. primate centers unravels the origin of SIVmac and SIVstm. J Virol 79: 8991-9005.

Bailes E, Gao F, Bibollet-Ruche F, Courgnaud V, Peeters M, Marx PA, Hahn BH, Sharp PM. 2003. Hybrid origin of SIV in chimpanzees. Science 300: 1713.

Barry AP, Silvestri G, Safrit JT, Sumpter B, Kozyr N, McClure HM, Staprans SI, Feinberg MB. 2007. Depletion of CD8 ${ }^{+}$ cells in sooty mangabey monkeys naturally infected with simian immunodeficiency virus reveals limited role for immune control of virus replication in a natural host species. J Immunol 178: 8002-8012.

Beaumier CM, Harris LD, Goldstein S, Klatt NR, Whitted S, McGinty J, Apetrei C, Pandrea I, Hirsch VM, Brenchley JM. 2009. CD4 downregulation by memory $\mathrm{CD}^{+} \mathrm{T}$ cells in vivo renders African green monkeys resistant to progressive SIVagm infection. Nat Med 15: 879-885.

Beer BE, Bailes E, Goeken R, Dapolito G, Coulibaly C, Norley SG, Kurth R, Gautier JP, Gautier-Hion A, Vallet D, et al. 1999. Simian immunodeficiency virus (SIV) from sun-tailed monkeys (Cercopithecus solatus): Evidence for host-dependent evolution of SIV within the C. lhoesti superspecies. J Virol 73: 7734-7744.

Beer BE, Bailes E, Dapolito G, Campbell BJ, Goeken RM, Axthelm MK, Markham PD, Bernard J, Zagury D, Franchini G, et al. 2000. Patterns of genomic sequence diversity among their simian immunodeficiency viruses suggest that L'Hoest monkeys (Cercopithecus lhoesti) are a natural lentivirus reservoir. J Virol 74: 3892-3898.

Beer BE, Foley BT, Kuiken CL, Tooze Z, Goeken RM, Brown CR, Hu J, St Claire M, Korber BT, Hirsch VM. 2001. Characterization of novel simian immunodeficiency viruses from red-capped mangabeys from Nigeria (SIVrcmNG409 and -NG411). J Virol 75: 12014-12027.

Beer BE, Brown CR, Whitted S, Goldstein S, Goeken R, Plishka R, Buckler-White A, Hirsch VM. 2005. Immunodeficiency in the absence of high viral load in pig-tailed 
macaques infected with simian immunodeficiency virus SIVsun or SIVlhoest. J Virol 79: 14044-14056.

Bibollet-Ruche F, Galat-Luong A, Cuny G, Sarni-Manchado P, Galat G, Durand JP, Pourrut X, Veas F. 1996. Simian immunodeficiency virus infection in a patas monkey (Erythrocebus patas): Evidence for cross-species transmission from African green monkeys (Cercopithecus aethiops sabaeus) in the wild. J Gen Virol 77: 773-781.

Bosinger SE, Li Q, Gordon SN, Klatt NR, Duan L, Xu L, Francella N, Sidahmed A, Smith AJ, Cramer EM, et al. 2009. Global genomic analysis reveals rapid control of a robust innate response in SIV-infected sooty mangabeys. J Clin Invest 119: 3556-3572.

Brenchley JM, Price DA, Schacker TW, Asher TE, Silvestri G, Rao S, Kazzaz Z, Bornstein E, Lambotte O, Altmann D, et al. 2006. Microbial translocation is a cause of systemic immune activation in chronic HIV infection. Nat Med 12: $1365-1371$.

Brenchley JM, Paiardini M, Knox KS, Asher AI, Cervasi B, Asher TE, Scheinberg P, Price DA, Hage CA, Kholi LM et al. 2008. Differential Th17 CD4 T-cell depletion in pathogenic and nonpathogenic lentiviral infections. Blood 112: 2826-2835.

Brenchley JM, Silvestri G, Douek DC. 2010. Nonprogressive and progressive primate immunodeficiency lentivirus infections. Immunity 32: 737-742.

Chahroudi A, Meeker T, Lawson B, Ratcliffe S, Else J, Silvestri G. 2011. Mother-to-infant transmission of simian immunodeficiency virus is rare in sooty mangabeys and is associated with low viremia. J Virol 85: 5757-S763.

Chakrabarti LA, Lewin SR, Zhang L, Gettie A, Luckay A, Martin LN, Skulsky E, Ho DD, Cheng-Mayer C, Marx PA. 2000. Normal T-cell turnover in sooty mangabeys harboring active simian immunodeficiency virus infection. J Virol 74: 1209-1223.

Clewley JP, Lewis JC, Brown DW, Gadsby EL. 1998. A novel simian immunodeficiency virus (SIVdrl) pol sequence from the drill monkey, Mandrillus leucophaeus. J Virol 72: 10305-10309.

Courgnaud V, Pourrut X, Bibollet-Ruche F, Mpoudi-Ngole E, Bourgeois A, Delaporte E, Peeters M. 2001. Characterization of a novel simian immunodeficiency virus from guereza colobus monkeys (Colobus guereza) in Cameroon: A new lineage in the nonhuman primate lentivirus family. J Virol 75: 857-866.

Courgnaud V, Salemi M, Pourrut X, Mpoudi-Ngole E, Abela B, Auzel P, Bibollet-Ruche F, Hahn B, Vandamme AM, Delaporte E, et al. 2002. Characterization of a novel simian immunodeficiency virus with a vpu gene from greater spot-nosed monkeys (Cercopithecus nictitans) provides new insights into simian/human immunodeficiency virus phylogeny. J Virol 76: 8298-8309.

Courgnaud V, Abela B, Pourrut X, Mpoudi-Ngole E, Loul S, Delaporte E, Peeters M. 2003. Identification of a new simian immunodeficiency virus lineage with a $v p u$ gene present among different Cercopithecus monkeys (C. mona, C. cephus, and C. nictitans) from Cameroon. J Virol 77: 12523-12534.

Dunham R, Pagliardini P, Gordon S, Sumpter B, Engram J, Moanna A, Paiardini M, Mandl JN, Lawson B, Garg S, et al. 2006. The AIDS resistance of naturally SIV-infected sooty mangabeys is independent of cellular immunity to the virus. Blood 108: 209-217.

Engram JC, Cervasi B, Borghans JA, Klatt NR, Gordon SN, Chahroudi A, Else JG, Mittler RS, Sodora DL, de Boer RJ, et al. 2010. Lineage-specific T-cell reconstitution following in vivo $\mathrm{CD}^{+}$and $\mathrm{CD} 8^{+}$lymphocyte depletion in nonhuman primates. Blood 116: 748-758.

Estes JD, Harris LD, Klatt NR, Tabb B, Pittaluga S, Paiardini M, Barclay GR, Smedley J, Pung R, Oliveira KM, et al. 2010. Damaged intestinal epithelial integrity linked to microbial translocation in pathogenic simian immunodeficiency virus infections. PLoS Pathog 6: e1001052.

Fauci AS. 2008. 25 years of HIV. Nature 453: 289-290.

Favre D, Lederer S, Kanwar B, Ma ZM, Proll S, Kasakow Z, Mold J, Swainson L, Barbour JD, Baskin CR, et al. 2009. Critical loss of the balance between Th17 and Tregulatory cell populations in pathogenic SIV infection. PLoS Pathog 5: e1000295.

Gaufin T, Pattison M, Gautam R, Stoulig C, Dufour J, MacFarland J, Mandell D, Tatum C, Marx MH, Ribeiro RM et al. 2009. Effect of B-cell depletion on viral replication and clinical outcome of simian immunodeficiency virus infection in a natural host. J Virol 83: 10347-10357.

Goldstein S, Brown CR, Ourmanov I, Pandrea I, BucklerWhite A, Erb C, Nandi JS, Foster GJ, Autissier P, Schmitz JE, et al. 2006. Comparison of simian immunodeficiency virus SIVagmVer replication and $\mathrm{CD} 4^{+} \mathrm{T}$-cell dynamics in vervet and sabaeus African green monkeys. J Virol 80: $4868-4877$.

Gordon SN, Klatt NR, Bosinger SE, Brenchley JM, Milush JM, Engram JC, Dunham RM, Paiardini M, Klucking S, Danesh A, et al. 2007. Severe depletion of mucosal $\mathrm{CD}^{+} \mathrm{T}$ cells in AIDS-free simian immunodeficiency virus-infected sooty mangabeys. J Immunol 179: 30263034.

Gordon SN, Dunham RM, Engram JC, Estes J, Wang Z, Klatt NR, Paiardini M, Pandrea IV, Apetrei C, Sodora DL, et al. 2008. Short-lived infected cells support virus replication in sooty mangabeys naturally infected with simian immunodeficiency virus: Implications for AIDS pathogenesis. J Virol 82: 3725-3735.

Grossman Z, Meier-Schellersheim M, Paul WE, Picker LJ. 2006. Pathogenesis of HIV infection: What the virus spares is as important as what it destroys. Nat Med 12: 289-295.

Haigwood NL. 2009. Update on animal models for HIV research. Eur J Immunol 39: 1994-1999.

Harris LD, Tabb B, Sodora DL, Paiardini M, Klatt NR, Douek DC, Silvestri G, Müller-Trutwin M, VasilePandrea I, Apetrei C, et al. 2010. Downregulation of robust acute type I interferon responses distinguishes nonpathogenic simian immunodeficiency virus (SIV) infection of natural hosts from pathogenic SIV infection of rhesus macaques. J Virol 84: 7886-7891.

Hirsch VM. 2004. What can natural infection of African monkeys with simian immunodeficiency virus tell us about the pathogenesis of AIDS? AIDS Rev 6: 40-53.

Hirsch VM, Olmsted RA, Murphey-Corb M, Purcell RH, Johnson PR. 1989. An African primate lentivirus (SIVsm) closely related to HIV-2. Nature 339: 389-392. 
N.R. Klatt et al.

Hirsch VM, Dapolito G, Goeken R, Campbell BJ. 1995a. Phylogeny and natural history of the primate lentiviruses, SIV and HIV. Curr Opin Genet Dev 5: 798-806.

Hirsch VM, Dapolito G, Johnson PR, Elkins WR, London WT, Montali RJ, Goldstein S, Brown C. 1995b. Induction of AIDS by simian immunodeficiency virus from an African green monkey: Species-specific variation in pathogenicity correlates with the extent of in vivo replication. J Virol 69: 955-967.

Ho DD, Neumann AU, Perelson AS, Chen W, Leonard JM, Markowitz M. 1995. Rapid turnover of plasma virions and CD4 lymphocytes in HIV-1 infection. Nature 373: $123-126$.

Hu J, Switzer WM, Foley BT, Robertson DL, Goeken RM, Korber BT, Hirsch VM, Beer BE. 2003. Characterization and comparison of recombinant simian immunodeficiency virus from drill (Mandrillus leucophaeus) and mandrill (Mandrillus sphinx) isolates. J Virol 77: 48674880.

Hunt PW, Brenchley J, Sinclair E, McCune JM, Roland M, Page-Shafer K, Hsue P, Emu B, Krone M, Lampiris H, et al. 2008. Relationship between $\mathrm{T}$ cell activation and $\mathrm{CD} 4^{+} \mathrm{T}$ cell count in HIV-seropositive individuals with undetectable plasma HIV RNA levels in the absence of therapy. J Infect Dis 197: 126-133.

Hurtrel B, Petit F, Arnoult D, Müller-Trutwin M, Silvestri G, Estaquier J. 2005. Apoptosis in SIV infection. Cell Death Differ 12: 979-990.

Jacquelin B, Mayau V, Targat B, Liovat AS, Kunkel D, Petitjean G, Dillies MA, Roques P, Butor C, Silvestri G, et al. 2009. Nonpathogenic SIV infection of African green monkeys induces a strong but rapidly controlled type I IFN response. J Clin Invest 119: 3544-3555.

Jin MJ, Rogers J, Phillips-Conroy JE, Allan JS, Desrosiers RC, Shaw GM, Sharp PM, Hahn BH. 1994a. Infection of a yellow baboon with simian immunodeficiency virus from African green monkeys: Evidence for cross-species transmission in the wild. J Virol 68: 8454-8460.

Jin MJ, Hui H, Robertson DL, Müller MC, Barré-Sinoussi F, Hirsch VM, Allan JS, Shaw GM, Sharp PM, Hahn BH. 1994b. Mosaic genome structure of simian immunodeficiency virus from west African green monkeys. $E M B O J$ 13: 2935-2947.

Johnson PR, Hirsch VM. 1991. Pathogenesis of AIDS: The non-human primate model. Aids 5: S43-S48.

Johnson PR, Hirsch VM. 1992. SIV infection of macaques as a model for AIDS pathogenesis. Int Rev Immunol 8: $55-63$.

Johnson PR, Goldstein S, London WT, Fomsgaard A, Hirsch VM. 1990. Molecular clones of SIVsm and SIVagm: Experimental infection of macaques and African green monkeys. J Med Primatol 19: 279-286.

Keele BF, Van Heuverswyn F, Li Y, Bailes E, Takehisa J, Santiago ML, Bibollet-Ruche F, Chen Y, Wain LV, Liegeois F, et al. 2006. Chimpanzee reservoirs of pandemic and nonpandemic HIV-1. Science 313: 523-526.

Keele BF, Jones JH, Terio KA, Estes JD, Rudicell RS, Wilson ML, Li Y, Learn GH, Beasley TM, Schumacher-Stankey J, et al. 2009. Increased mortality and AIDS-like immunopathology in wild chimpanzees infected with SIVcpz. Nature 460: 515-519.
Kim N, Dabrowska A, Jenner RG, Aldovini A. 2007. Human and simian immunodeficiency virus-mediated upregulation of the apoptotic factor TRAIL occurs in antigenpresenting cells from AIDS-susceptible but not from AIDS-resistant species. J Virol 81: 7584-7597.

Kirmaier A, Wu F, Newman RM, Hall LR, Morgan JS, O'Connor S, Marx PA, Meythaler M, Goldstein S, Buckler-White A, et al. 2010. TRIM5 suppresses crossspecies transmission of a primate immunodeficiency virus and selects for emergence of resistant variants in the new species. PLoS Biol 8: e1000462.

Klatt NR, Brenchley JM. 2010. Th17 cell dynamics in HIV infection. Curr Opin HIVAIDS 5: 135-140.

Klatt NR, Villinger F, Bostik P, Gordon SN, Pereira L, Engram JC, Mayne A, Dunham RM, Lawson B, Ratcliffe SJ, et al. 2008. Availability of activated $\mathrm{CD} 4^{+} \mathrm{T}$ cells dictates the level of viremia in naturally SIV-infected sooty mangabeys. J Clin Invest 118: 2039-2049.

Klatt NR, Shudo E, Ortiz AM, Engram JC, Paiardini M, Lawson B, Miller MD, Else J, Pandrea I, Estes JD, et al. 2010. $\mathrm{CD}^{+}$lymphocytes control viral replication in SIVmac239-infected rhesus macaques without decreasing the lifespan of productively infected cells. PLoS Pathog 6: e1000747.

Kosub DA, Lehrman G, Milush JM, Zhou D, Chacko E, Leone A, Gordon S, Silvestri G, Else JG, Keiser P, et al. 2008. Gamma/delta-cell functional responses differ after pathogenic human immunodeficiency virus and nonpathogenic simian immunodeficiency virus infections. $J$ Virol 82: 1155-1165.

Lederer S, Favre D, Walters KA, Proll S, Kanwar B, Kasakow Z, Baskin CR, Palermo R, McCune JM, Katze MG. 2009. Transcriptional profiling in pathogenic and non-pathogenic SIV infections reveals significant distinctions in kinetics and tissue compartmentalization. PLoS Pathog 5: e1000296.

Letvin NL, Mascola JR, Sun Y, Gorgone DA, Buzby AP, Xu L, Yang ZY, Chakrabarti B, Rao SS, Schmitz JE, et al. 2006. Preserved $\mathrm{CD}^{+}{ }^{+}$central memory $\mathrm{T}$ cells and survival in vaccinated SIV-challenged monkeys. Science 312: 1530 1533.

Li B, Stefano-Cole K, Kuhrt DM, Gordon SN, Else JG, Mulenga J, Allen S, Sodora DL, Silvestri G, Derdeyn CA. 2010. Nonpathogenic simian immunodeficiency virus infection of sooty mangabeys is not associated with high levels of autologous neutralizing antibodies. J Virol 84: 6248-6253.

Ling B, Apetrei C, Pandrea I, Veazey RS, Lackner AA, Gormus B, Marx PA. 2004. Classic AIDS in a sooty mangabey after an 18-year natural infection. J Virol 78: 8902-8908.

Mandl JN, Barry AP, Vanderford TH, Kozyr N, Chavan R, Klucking S, Barrat FJ, Coffman RL, Staprans SI, Feinberg MB. 2008. Divergent TLR7 and TLR9 signaling and type I interferon production distinguish pathogenic and nonpathogenic AIDS virus infections. Nat Med 14: 1077-1087.

Mattapallil JJ, Douek DC, Buckler-White A, Montefiori D, Letvin NL, Nabel GJ, Roederer M. 2006. Vaccination preserves CD4 memory $\mathrm{T}$ cells during acute simian immunodeficiency virus challenge. J Exp Med 203: 1533-1541.

McCune JM. 2001. The dynamics of $\mathrm{CD} 4^{+}$T-cell depletion in HIV disease. Nature 410: 974-979. 
Milush JM, Reeves JD, Gordon SN, Zhou D, Muthukumar A, Kosub DA, Chacko E, Giavedoni LD, Ibegbu CC, Cole KS, et al. 2007. Virally induced $\mathrm{CD} 4^{+} \mathrm{T}$ cell depletion is not sufficient to induce AIDS in a natural host. J Immunol 179: 3047-3056.

Milush JM, Mir KD, Sundaravaradan V, Gordon SN, Engram J, Cano CA, Reeves JD, Anton E, O’Neill E, Butler E, et al. 2011. Lack of clinical AIDS in SIVinfected sooty mangabeys with significant $\mathrm{CD} 4^{+} \mathrm{T}$ cell loss is associated with double-negative T cells. J Clin Invest 121: 1102-1110.

Muller MC, Barre-Sinoussi F. 2003. SIVagm: Genetic and biological features associated with replication. Front Biosci 8: d1170-d1185.

Murphey-Corb M, Martin LN, Rangan SR, Baskin GB, Gormus BJ, Wolf RH, Andes WA, West M, Montelaro RC. 1986. Isolation of an HTLV-III-related retrovirus from macaques with simian AIDS and its possible origin in asymptomatic mangabeys. Nature 321: 435-437.

Novembre FJ, Saucier M, Anderson DC, Klumpp SA, O’Neil SP, Brown CR II, Hart CE, Guenthner PC, Swenson RB, McClure HM. 1997. Development of AIDS in a chimpanzee infected with human immunodeficiency virus type 1 . J Virol 71: 4086-4091.

Nowak MA, Lloyd AL, Vasquez GM, Wiltrout TA, Wahl LM, Bischofberger N, Williams J, Kinter A, Fauci AS, Hirsch VM, et al. 1997. Viral dynamics of primary viremia and antiretroviral therapy in simian immunodeficiency virus infection. J Virol 71: 7518-7525.

Okoye A, Meier-Schellersheim M, Brenchley JM, Hagen SI, Walker JM, Rohankhedkar M, Lum R, Edgar JB, Planer SL, Legasse A, et al. 2007. Progressive $\mathrm{CD}^{+}{ }^{+}$central memory $\mathrm{T}$ cell decline results in $\mathrm{CD} 4^{+}$effector memory insufficiency and overt disease in chronic SIV infection. J Exp Med 204: 2171-2185.

Onanga R, Souquière S, Makuwa M, Mouinga-Ondeme A, Simon F, Apetrei C, Roques P. 2006. Primary simian immunodeficiency virus SIVmnd-2 infection in mandrills (Mandrillus sphinx). J Virol 80: 3301-3309.

O'Neil SP, Novembre FJ, Hill AB, Suwyn C, Hart CE, Evans-Strickfaden T, Anderson DC, deRosayro J, Herndon JG, Saucier M, et al. 2000. Progressive infection in a subset of HIV-1-positive chimpanzees. J Infect Dis 182: $1051-1062$.

Paiardini M. 2010. Th17 cells in natural SIV hosts. Curr Opin HIVAIDS 5: 166-172.

Paiardini M, Cervasi B, Dunham R, Sumpter B, Radziewicz H, Silvestri G. 2004. Cell-cycle dysregulation in the immunopathogenesis of AIDS. Immunol Res 29: 253268.

Paiardini M, Cervasi B, Sumpter B, McClure HM, Sodora DL, Magnani M, Staprans SI, Piedimonte G, Silvestri G. 2006. Perturbations of cell cycle control in T cells contribute to the different outcomes of simian immunodeficiency virus infection in rhesus macaques and sooty mangabeys. J Virol 80: 634-642.

Paiardini M, Pandrea I, Apetrei C, Silvestri G. 2009a. Lessons learned from the natural hosts of HIV-related viruses. Annu Rev Med 60: 485-495.

Paiardini M, Pandrea I, Apetrei C, Silvestri G. 2009b. Lessons learned from the natural hosts of HIV-related viruses. Ann Rev Med 60: 485-495.
Paiardini M, Cervasi B, Reyes-Aviles E, Micci L, Ortiz AM, Chahroudi A, Vinton C, Gordon SN, Bosinger SE, Francella N, et al. 2011. Low levels of SIV infection in sooty mangabey central-memory $\mathrm{CD} 4^{+}$T-cells is associated with limited CCR5 expression. Nat Med (in press).

Pandrea I, Onanga R, Kornfeld C, Rouquet P, Bourry O, Clifford S, Telfer PT, Abernethy K, White LT, Ngari P, et al. 2003. High levels of SIVmnd-1 replication in chronically infected Mandrillus sphinx. Virology 317: 119-127.

Pandrea I, Silvestri G, Onanga R, Veazey RS, Marx PA, Hirsch V, Apetrei C. 2006a. Simian immunodeficiency viruses replication dynamics in African non-human primate hosts: Common patterns and species-specific differences. J Med Primatol 35: 194-201.

Pandrea I, Apetrei C, Dufour J, Dillon N, Barbercheck J, Metzger M, Jacquelin B, Bohm R, Marx PA, BarreSinoussi F, et al. 2006b. Simian immunodeficiency virus SIVagm.sab infection of Caribbean African green monkeys: A new model for the study of SIV pathogenesis in natural hosts. J Virol 80: 4858-4867.

Pandrea IV, Gautam R, Ribeiro RM, Brenchley JM, Butler IF, Pattison M, Rasmussen T, Marx PA, Silvestri G, Lackner $\mathrm{AA}$, et al. 2007a. Acute loss of intestinal $\mathrm{CD}^{+} \mathrm{T}$ cells is not predictive of simian immunodeficiency virus virulence. J Immunol 179: 3035-3046.

Pandrea I, Apetrei C, Gordon S, Barbercheck J, Dufour J, Bohm R, Sumpter B, Roques P, Marx PA, Hirsch VM, et al. 2007b. Paucity of $\mathrm{CD} 4^{+} \mathrm{CCR} 5^{+} \mathrm{T}$ cells is a typical feature of natural SIV hosts. Blood 109: 1069-1076.

Pandrea I, Ribeiro RM, Gautam R, Gaufin T, Pattison M, Barnes M, Monjure C, Stoulig C, Dufour J, Cyprian W, et al. 2008a. Simian immunodeficiency virus SIVagm dynamics in African green monkeys. J Virol 82: 37133724.

Pandrea I, Gaufin T, Brenchley JM, Gautam R, Monjure C, Gautam A, Coleman C, Lackner AA, Ribeiro RM, Douek DC, et al. 2008b. Cutting edge: Experimentally induced immune activation in natural hosts of SIV induces significant increases in viral replication and $\mathrm{CD} 4^{+} \mathrm{T}$ cell depletion. J Immunol 181: 6687-6691.

Pandrea I, Silvestri G, Apetrei C. 2009. AIDS in african nonhuman primate hosts of SIVs: A new paradigm of SIV infection. Curr HIV Res 7: 57-72.

Pandrea I, Apetrei C. 2010. Where the wild things are: Pathogenesis of SIV infection in African nonhuman primate hosts. Curr HIV/AIDS Rep 7: 28-36.

Peeters M, Chaix ML, Delaporte E. 2008. Genetic diversity and phylogeographic distribution of SIV: How to understand the origin of HIV. Med Sci (Paris) 24: 621-628.

Perelson AS, Kirschner DE, De Boer R. 1993. Dynamics of HIV infection of CD4 ${ }^{+} \mathrm{T}$ cells. Math Biosci 114: 81-125.

Perelson AS, Essunger P, Cao Y, Vesanen M, Hurley A, Saksela K, Markowitz M, Ho DD. 1997. Decay characteristics of HIV-1-infected compartments during combination therapy. Nature 387: 188-191.

Picker LJ. 2006. Immunopathogenesis of acute AIDS virus infection. Curr Opin Immunol 18: 399-405.

Rey-Cuillé MA, Berthier JL, Bomsel-Demontoy MC, Chaduc Y, Montagnier L, Hovanessian AG, Chakrabarti LA. 1998. Simian immunodeficiency virus replicates to high levels in sooty mangabeys without inducing disease. J Virol 72: $3872-3886$. 


\section{N.R. Klatt et al.}

Riddick NE, Hermann EA, Loftin LM, Elliott ST, Wey WC, Cervasi B, Taaffe J, Engram JC, Li B, Else JG, et al. 2010. A novel CCR5 mutation common in sooty mangabeys reveals SIVsmm infection of CCR5-null natural hosts and efficient alternative coreceptor use in vivo. PLoS Pathog 6: e1001064.

Rotger M, Dalmau J, Rauch A, McLaren P, Bosinger S, Martinez R, Sandler NG, Roque A, Liebner J, Battegay $\mathrm{M}$, et al. 2011. Comparative transcriptomics of extreme phenotypes of human HIV-1 infection and SIV infection in sooty mangabey and rhesus macaque. J Clin Invest 121: 2391-2400.

Sauter D, Schindler M, Specht A, Landford WN, Münch J, Kim KA, Votteler J, Schubert U, Bibollet-Ruche F, Keele BF, et al. 2009. Tetherin-driven adaptation of $\mathrm{Vpu}$ and Nef function and the evolution of pandemic and nonpandemic HIV-1 strains. Cell Host Microbe 6: 409-421.

Schmitz JE, Kuroda MJ, Santra S, Sasseville VG, Simon MA, Lifton MA, Racz P, Tenner-Racz K, Dalesandro M, Scallon BJ, et al. 1999. Control of viremia in simian immunodeficiency virus infection by $\mathrm{CD} 8^{+}$lymphocytes. Science 283: $857-860$.

Schmitz JE, Zahn RC, Brown CR, Rett MD, Li M, Tang H, Pryputniewicz S, Byrum RA, Kaur A, Montefiori DC, et al. 2009. Inhibition of adaptive immune responses leads to a fatal clinical outcome in SIV-infected pigtailed macaques but not vervet African green monkeys. PLoS Pathog 5: e1000691.
Sharp PM, Hahn BH. 2010. The evolution of HIV-1 and the origin of AIDS. Philos Trans R Soc Lond B Biol Sci 365: 2487-2494.

* Sharp PM, Hahn BH. 2011. Origins of HIV and the AIDS pandemic. Cold Spring Harb Perspect Med 1: a006841.

Silvestri G, Sodora DL, Koup RA, Paiardini M, O'Neil SP, McClure HM, Staprans SI, Feinberg MB. 2003. Nonpathogenic SIV infection of sooty mangabeys is characterized by limited bystander immunopathology despite chronic high-level viremia. Immunity 18: 441-452.

Sodora DL, Allan JS, Apetrei C, Brenchley JM, Douek DC, Else JG, Estes JD, Hahn BH, Hirsch VM, Kaur A, et al. 2009. Toward an AIDS vaccine: Lessons from natural simian immunodeficiency virus infections of African nonhuman primate hosts. Nat Med 15: 861-865.

Sumpter B, Dunham R, Gordon S, Engram J, Hennessy M, Kinter A, Paiardini M, Cervasi B, Klatt N, McClure H, et al. 2007. Correlates of preserved $\mathrm{CD} 4^{+} \mathrm{T}$ cell homeostasis during natural, nonpathogenic simian immunodeficiency virus infection of sooty mangabeys: Implications for AIDS pathogenesis. J Immunol 178: 1680-1691.

Wei X, Ghosh SK, Taylor ME, Johnson VA, Emini EA, Deutsch P, Lifson JD, Bonhoeffer S, Nowak MA, Hahn BH, et al. 1995. Viral dynamics in human immunodeficiency virus type 1 infection. Nature 373: 117-122.

Worobey M, Telfer P, Souquière S, Hunter M, Coleman CA, Metzger MJ, Reed P, Makuwa M, Hearn G, Honarvar S, et al. 2010. Island biogeography reveals the deep history of SIV. Science 329: 1487. 


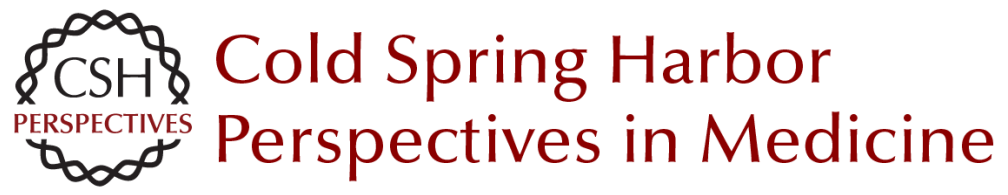

\section{Nonpathogenic Simian Immunodeficiency Virus Infections}

Nichole R. Klatt, Guido Silvestri and Vanessa Hirsch

Cold Spring Harb Perspect Med 2012; doi: 10.1101/cshperspect.a007153 originally published online September 7, 2011

\section{Subject Collection HIV}

HIV Pathogenesis: Dynamics and Genetics of

Viral Populations and Infected Cells John Coffin and Ronald Swanstrom

Human Immunodeficiency Virus Vaccine Trials Robert J. O'Connell, Jerome H. Kim, Lawrence Corey, et al.

HIV Transmission George M. Shaw and Eric Hunter

Novel Cell and Gene Therapies for HIV James A. Hoxie and Carl H. June

Behavioral and Biomedical Combination Strategies for HIV Prevention Linda-Gail Bekker, Chris Beyrer and Thomas C. Quinn

HIV-1 Assembly, Budding, and Maturation Wesley I. Sundquist and Hans-Georg Kräusslich

HIV-1 Assembly, Budding, and Maturation Wesley I. Sundquist and Hans-Georg Kräusslich

Lessons in Nonhuman Primate Models for AIDS Vaccine Research: From Minefields to Milestones Jeffrey D. Lifson and Nancy L. Haigwood
HIV-1 Pathogenesis: The Virus Ronald Swanstrom and John Coffin

The T-Cell Response to HIV Bruce Walker and Andrew McMichael

HIV-1 Reverse Transcription Wei-Shau Hu and Stephen H. Hughes

HIV Pathogenesis: The Host A.A. Lackner, Michael M. Lederman and Benigno Rodriguez

HIV: Cell Binding and Entry Craig B. Wilen, John C. Tilton and Robert W. Doms

Innate Immune Control of HIV Mary Carrington and Galit Alter

HIV DNA Integration Robert Craigie and Frederic D. Bushman HIV-1-Related Central Nervous System Disease: Current Issues in Pathogenesis, Diagnosis, and Treatment Serena Spudich and Francisco González-Scarano

For additional articles in this collection, see http://perspectivesinmedicine.cshlp.org/cgi/collection/ 